\title{
100 Temel Eser'de Kadın İmgesinin İncelenmesi
}

\author{
Erkan Çer ${ }^{1}$
}

\begin{abstract}
$\ddot{O} z$
Yazınsal nitelikli çocuk kitapları, yansıtmış olduğu olay, durum, karakter ve görseller aracılığlyla çocuk okurun cinsel kimliğini, benlik algısını ve toplumsal rolünü etkiler. Çocuk edebiyatı yapıtlarında yer alan bu öğeler, yaratıldı̆̆ toplumun kültürel ve toplumsal değerleriyle oluşur ve çocuğun kadın ve erkek cinsiyetine yönelik algısını biçimlendirir. Bu biçimlenmenin temelinde, sosyal, kültürel ve ekonomik değerler vardır. Bu yönüyle, çocuk edebiyatı yapıtları oluşturulurken kültürel ve toplumsal değerler, eğitsel ilkeler bakımından sorgulandıktan sonra çocuk okura sunulması gerekir. Çünkü geleneksel değerleri bünyesinde taşıyan çocuk edebiyatı yapıtları, kadını ve erkeğin toplumsal rolünü ve haklarını farklı gösterebilir; kadını toplum dışına itebilir, kadını cinsel bir nesne olarak sunabilir. Bu durumda, çocuk okurlar, kendi cinsiyetine yüklenen rollere ilişkin geleneksel/kalıp yargıya dayalı bir algı geliştirebilir. Kadın ve erkeğe yüklenen anlamın çocuk edebiyatı yapıtlarına olumsuz bir biçimde yansıması, çocuk okurun, kadın ve erkeğe yönelik algısında (cinsel kimlik, toplumsal cinsiyet) kalıc etkiler yaratabilir. Türkiye’de Milli Ĕ̈itim Bakanliğl, "100 Temel Eser" adı altında içinde öykü, roman, şiir, tekerleme ve manilerin bulunduğu bir liste önermiştir. Bu listedeki öykülerde, "kadın imgesi”"nin nasıl yer aldığııın bilinmesi gerekir.
\end{abstract}

Anahtar Sözcükler: Çocuk edebiyatı, 100 temel eser, Kadın imgesi, Toplumsal cinsiyet, Öykü

\section{Investigation of Woman Image in 100 Basic Literary}

\begin{abstract}
Literary children books affect sexual identity, self-perception, and social role of child reader via the event, situation, character, and visuals it reflected. These elements covered by children literacy books consist of the cultural and social values of the society in which they are created and form the perception of child about male and female sexes. In the basis of this form, there is a socialization process developed by social, cultural, and economic values of the period. In this regard, while creating children literature books, cultural and social values are required to be presented to the child reader after questioning in terms of educational principles. Because, the children books covering traditional values might show the role and rights of male and female differently; might push woman out of the society; and might present woman as a sexual object. In this instance, child readers might develop a traditional/negative perception about the roles attributed to their sexes. The negative reflection of the meaning attributed to male and female in children literacy books might impact permanently the perception of child reader about male and female(Sexual identity, Social role). Minister of National Education has recommended a list called "100 Basic Books", which includesnarratives, novel, poetry, nursery rhyme, and mania for the purpose of creating reading custom and culture. It is needed to know how those narratives on this list present woman.
\end{abstract}

Keywords: Children literature, 100 basic books, Woman image, Sexual roles, Narratives

1 Öğr. Gör., Amasya Üniversitesi, Eğitim Fakültesi, Türkçe Eğitimi Bölümü, E-mail: erkan.cer@gmail.com, Tel: 05334090114 


\section{Giriş}

Yazınsal nitelikli çocuk kitaplarında, çocukların yeni yaşantılar kazanmalarına olanak sağlayan en temel öğelerden biri, öyküdeki kahraman/kahramanlar ve onların nitelikleridir (Sever, 2008). Çocuklar, kendilerine sunulan karakterin davranışlarını, fiziksel özelliklerini ve olaylar karşısındaki duygu ve düşüncelerini inceler; özellikle yaşamın ilk yıllarında kendisi gibi küçük çocuk ve hayvan karakterlere ilgi duyar (Walter, 1966; Güleryüz, 2003; Nas, 2004; Yalçın ve Aktaş, 2005; Sever, 2008; Uyar, 2013). Kahramanların fiziksel ve ruhsal özellikleri ile öyküdeki olayla yön veren kişiliği, çocukları kahraman/kahramanlarla özdeşim kurmaya yöneltir (Sever, 2008). Bu yönüyle karakter eylem ve davranışlarıyla, dış görünüşü ve diğer karakterler ile ilişkisiyle (Hearne, 2000; Sever, 2008) çocuk okurun kendine ve yaşama yönelik algısını değiştirir (Gooden ve Gooden, 2001).

Çocuklar, cinsiyet kimliklerini oluştururken yazınsal nitelikli çocuk kitaplarında geçen karakterlerin toplumsal cinsiyetçi rollerini benimseyebilir (LaDow, 1976). Kahramanın yaşama bağl1lığ1, karşılaştığ1 sorunları çözmedeki kararlılı̆̆1, amaca ulaşmada izlediği yöntemlerin niteliği ve bu eylemler bileşkesinin söz ve davranışlarla somutlanması, çocukları da kahraman gibi duymaya, düşünmeye ve hareket etmeye istekli kılar (Scott ve Feldman- Summers, 1979; Sever, 2008).

Bir masalda, öyküde, romanda ya da bir anlatıda geçen karakter, toplumsal ve kültürel özelliklere göre biçimlenir. Bu biçimlendirmede kadın ve erkek karakterlerin toplumsal rolleri, hakları ve kendilerine yüklenen anlam, çocuk okurun kendine ve yaşama yönelik cinsiyet algısını etkiler. Bu yönüyle çocuk okurlar, erken dönemden başlayarak cinsiyet rollerini basmakalıp bir şekilde öğrenirler (Gooden ve Gooden, 2001). Böylelikle geleneksel/basmakalıp cinsiyetçi roller, çocuğun kadın ve erkeğe yönelik algısını biçimlendirir (Narahana, 1998).

Toplumsal cinsiyetçi roller, çocukların sosyal yaşamlarını anlamlı kılmak ve uyum sağlamalarını kolaylaştırmak için oluşturulmuş bilişsel bir çerçevedir (Macklin ve Kolbe, 1984). Bu kavram, sosyal yaşamda kadın ve erkeğin nasıl davranması gerektiğini betimler (Macklin ve Kolbe, 1984). Aynı zamanda, doğuştan kazanılan cinsiyetten farklı olarak, toplumsal ve kültürel olarak kadına ve erkeğe yüklenen rolleri anlatır (Cincotta, 1978; Wharton, 2005). Toplumsal cinsiyet, kadın ve erkek olarak toplumun bizi nasıl gördüğü, nasıl alg1ladığı, nasıl düşündüğü ve nasıl davranmamızı beklediği ile ilgili bir tanımlamadır (Dökmen, 2006). Çünkü çocuk doğar doğmaz aile, toplumsal ve kültürel yapıya göre (toplumsal cinsiyet) çocuğu yetiştirmeye başlar (Bhasin, 2003).

Tüm toplumsal rolleri kadın ve erkeğin biyolojik cinsiyetiyle ilişkilendirmek ya da cinslerden birine daha fazla öncelik vermek cinsiyetçilik olduğuna göre (Brown, 1994), geleneksel/basmakalıp toplumsal cinsiyetçi rollerin çocuk kitaplarında betimlenmesi, çocukların tutum ve davranışlarını etkileyebilir (Anderson ve Hamilton, 2005). Çünkü yazınsal nitelikli çocuk kitapları, çocukların toplumsal cinsiyetçi rollerini öğrenmeleri için önemli bir araçtır (Taylor, 2003). Bu yönüyle, çocuk edebiyatı yapıtlarında, cinsiyetin tektipleştirilerek betimlenmesi ve kadın karakterin yetersiz bir biçimde sunulması; çocuğun cinsiyet algısına olumsuz katkı sağlar (Hamilton, Anderson, Broaddus ve Young, 2006).

Çocuk edebiyatı yapıtlarında karakter, sanatçının yarattığı; duygu, düşünce ve tutku yönleriyle geliştirdiği, gerçek yaşamdan da esinlenerek deneyimiyle, birikimiyle, kendine özgü duyarlığı ile biçimlendirdiği bir kişiliktir (Sever, 2008). Bu kişiliğin toplumsal cinsiyetçi rol model olması (Narahana, 1998), erkeğe ve kadına yüklenen anlamı etkiler (Gooden ve Gooden, 2001; 
Taylor, 2003; Bem, 1981). Oysa kadına ve erkeğe özgü özellikler doğuştan değildir; sonradan edinilir (Bern, 1981; Eagly ve Wood, 1999). Çocuk kitaplarında erkek karakterin daha etkin bir biçimde gösterilirken kadının daha edilgen gösterilmesi ya da erkek karakter iş sahibi olmasına karşın kadın karakterin evli ve anne olarak gösterilmesi geleneksel/basmakalıp toplumsal cinsiyetçi anlayışı yansitır (Anderson ve Hamilton, 2005). Bu yönüyle çocuk kitaplarındaki toplumsal cinsiyetçi ön yarg1 (Hamilton, Anderson, Broaddus ve Young, 2006), genelleştirilmiş/tektipleştirilmiş öteki (Bern, 1981) kavramını erken dönemde çocuğun bilişsel çerçevesine yerleştirir (Macklin ve Kolbe, 1984). Bu açıdan baktığımızda çocuk kitapları, toplumsal cinsiyetçi bakış açısının, baskın kültürden etkilenen inançların, değerlerin ve ideolojilerin olduğu küçük bir evren sunar. Bu evren içerisinde çocuk okur, kendi cinsiyetine yönelik toplumsal ve kültürel simgeleri öğrenir (Taylor, 2003).

Geleneksel değer yargıları, kalıplar, toplum belleğine yerleşmiş konumlandırma ve ön yargılı bakış açıları kadın ve erkek arasındaki ayrımcı bakış açısını derinleştirmektedir (Dolmacı ve Şalvarcı Türeli, 2012). Yazınsal nitelikli çocuk kitaplarında, resim, fotoğraf ve dilsel metinlerde sunulan kadın ve erkek betimleri (figür), bunların konunun özelliğine göre yer alış biçimleri çocukların cinsiyet rollerinin oluşmasında etkili olmaktadır (Dökmen, 2010). Çünkü kültürün etkisiyle toplumda bireylerin rolleri biçimlenmiştir. Yaşamın her anında ortaya çıkan toplumsal rollerin belirlenmesinde cinsiyet öne çıkarılmıştır (Özkan, 2013).

Bir kız çocuğunun bedeninde onu şort giymekten, ağaca tırmanmaktan ya da bisiklete binmekten alıkoyan hiçbir şey yoktur. Bir erkek çocuğun bedeninde de onu bebeklerle oynamaktan, kendinden daha küçük kardeşleriyle ilgilenmekten, yemek hazırlamaya ya da temizlik yapmaya yardımcı olmaktan alıkoyan hiçbir şey yoktur (Çelik, 2008). Farklılıklar, toplumsal cinsiyetteki farklılıklardır ve toplum tarafından yaratılır (Bhasin, 2003). Çocuklara sunulan dilsel ve görsel metinler ile oyuncaklar ve televizyon yayınları kadın ve erkek arasındaki farklılıkları vurgulama eğilimindedir. Sözgelimi, kız çocuklara karakter olarak yavru kedi ya da tavşan önerilirken; erkek çocuklara aslan ya da kaplan önerilmiştir (Giddens, 2000). Masallarda anlatılan erkek kahramanlar güçlü, savaşcı, sonunda hep kazanan ve kurtaran kişilerdir; kadılarsa genellikle zayıf, kurtarıcı bekleyen, duygusal, iyi niyetli ve şefkatlidir (Giddens, 2000). Toplumun kadınlardan ve erkeklerden kendi cinsiyetlerine yöne bekledikleri davranışlar, toplumsal cinsiyet kalıpyargılarıdır. Cinsiyet rollerine ilişkin kalıpyargıların karakter aracılığıyla açık ve örtülü iletilerle çocuklara sunulması söz konusudur (Dökmen, 2006). Bu kalıpyargıların sunulduğu en etkili araçların başında dilsel ve görsel metinler vardır. Çünkü bu metinler, çocukların algılarını hep belirli kadın ve erkek modelleri ile doldurarak belirli kalıpyargılar ve tutumlar kazanmalarında pekiştirici rol üstlenmektedir (Dökmen, 2006). Bu metinlerde kadınlardan beklenen daha çok çocukları, eşleri ve evleri ile ilgilenmeleri, duygusal yönden sakin, fedakar, duyarlı vb. davranışları sergilemeleri iken erkeklerden daha çok evinin gereksinmesini karşılayan, ailesini koruyup kollayan, duygusal açıdan güçlü, özverili, çalışkan vb. olması beklenmektedir (Çelik, 2008).

\section{Çalışmanın Amacı}

Bu çalışmanın amacı, “100 Temel Eser” listesindeki öykülerin kadın imgesini nasıl ve ne düzeyde sunduğunu ortaya koymaktır. 


\section{Yöntem}

$\mathrm{Bu}$ çalışmada, betimsel bir yöntem olan doküman incelemesi kullanılmıştır. Doküman incelemesi, araştırılması hedeflenen olgu veya olgular hakkında bilgi içeren yazılı materyallerin çözümlenmesini kapsar. Dokümanlar, nitel araştırmalarda etkili bir şekilde kullanılması gereken önemli bilgi kaynaklarıdır (Yıldırım ve Şimşek, 2011: 187-188). Araştırma problemine ilişkin olarak yazılı ve görsel dokümanların incelenmesi daha zengin ve kapsamlı bir çıkarım sağlanması açısından oldukça önemlidir (Baş ve Akturan, 2008, s.117).

\section{Veri Toplama Aracı ve Verilerin Çözümlenmesi}

$\mathrm{Bu}$ çalışmada veriler, doküman incelemesiyle toplanmış ve verilere içerik çözümlenmesi uygulanmıştır. Metin, kitap, belge vb. malzemenin belli özelliklerinin belirlenmesi amacı ile yapılan analiz olarak da nitelendirilebilen içerik çözümlemesi, nicelleştirme ölçülerini önceden geliştirerek, malzemeyi belli beklentiler 1şığında incelemektir (Karasar, 2011, s.184). Tavşancıl ve Aslan (2001, s.87)'a göre, içerik çözümlemesi türünden sıklık çözümlemesi ile birimlerin nicel olarak görünme sıklığı ortaya konur. Yıldırım ve Şimşek (2011, s.246)'e göre, çözümleme birimi olarak kullanabilecek ikinci kaynak tümcedir. Başı ve sonu belirgin analitik bir ünite olması açısından, nitel verilerin sayısallaştırılmasında önemli olan tümce, araştırmacın bir nitel veri setine ilişkin izlek (tema) veya kategoriler kullanacağı en önemli araçtır.

Bu yönüyle betimsel nitelikli olan bu çalışmada, “100 Temel Eser” adlı çocuk kitaplarında yer alan öykülerdeki "kadın imgesi” içerik çözümlemesi türünde sıklık çözümlemesi (frekans analizi) tekniği kullanılarak incelenmiştir. Sıklık çözümlemesi (frekans analizi), en basit biçimiyle, birim veya ögelerin sayısal, yüzdesel ve oransal bir tarzda görünme sıklığını ortaya koymaktadır. Bu belirli bir ögenin yoğunluğunu ve önemini anlamayı sağlar (Karasar, 2011: 184; Balc1, 2010, s.212). Metinlerin incelenmesinde ve siklıklarının belirlenmesinde tüm tümceler dikkate alınarak inceleme yapılmıştır. Çalışmaya bağlam birimi olarak "tümceler" alınmıştır.

Çalışmada ana kategori olarak “kadın imgesi» ele alınmıştır. Macionis (2001)'in “geleneksel/ kalıpyargılara dayalı cinsiyet" anlayışının yansıttığg kadına yönelik izlekler (tema), çalışmanın alt kategorilerini oluşturmaktadır. Bu alt kategoriler; "alçakgönüllü, bağımlı, duygusal, zeki olmayan, anlayışl1, sezgisel, güçsüz, utangaç, korkak, memnun, edilgen, işbirlikçi, hassas, cinsel nesne, fiziksel görünüme göre çekici” olarak belirlenmiştir.

\section{Bulgular ve Yorum}

Bu çalışmada, "100 Temel Eser" adlı çocuk kitaplarında yer alan öyküler, "kadın imgesi" bakımından incelenmiştir. Öykü kitapları incelendiğinde, kadının daha çok fiziksel görünüm olarak çekici, edilgen, cinsel nesne, güçsüz ve korkak olarak sunulduğu dikkat çekmektedir. 
Tablo 1. “100 Temel Eser”deki Öykülerin “Kadın Imgesi”sine Yönelik Kodlamalarının Siklıkları ve Yüzdeleri

\begin{tabular}{lcc}
\hline Kadın imgesi & f & \% \\
\hline Cinsel nesne & 30 & 8.17 \\
\hline Bağımlı & 14 & 3.81 \\
\hline Duygusal & 35 & 9.53 \\
\hline Alçakgönüllü & 26 & 7.08 \\
\hline Anlayışlı & 20 & 5.44 \\
\hline Sezgisel & 3 & 0.81 \\
\hline Güçsüz & 36 & 9.80 \\
\hline Korkak & 28 & 7.62 \\
\hline Memnun & 24 & 6.53 \\
\hline Edilgen & 45 & 12.26 \\
\hline İsirlikçi & 14 & 3.81 \\
\hline Hassas & 36 & 9.80 \\
\hline Zeki olmayan & 1 & 0.27 \\
\hline Fiziksel görünüm olarak çekici & 55 & 14.98 \\
\hline Toplam & $\mathbf{3 6 7}$ & $\mathbf{1 0 0}$ \\
\hline
\end{tabular}

Tablo 1, öyküler "kadın imgesi" bakımından incelendiğinde, kadının en fazla "fiziksel görünüm olarak çekici” (\% 14.98) olarak sunulduğu görülmektedir. Bunu da sirasiyla "edilgen" (\% 12.26), "güçsüz" (\% 9.80), "hassas" (\% 9.80), "duygusal” (\% 9.53), "cinsel nesne” (\% 8.17), "korkak" (\% 7.62), "alçakgönüllü” (\% 7.08), "memnun” (\% 6.53), "anlayışlı" (\% 5.44), "işbirlikçi”" (\% 3.81), "bağımlı" (\% 3.81), "sezgisel” (\% 0.81), "zeki olmayan” (\% 0.27) izlemektedir. "100 Temel Eser” adlı çocuk kitaplarında geçen alt kategorilere ilişkin örnekler aşağıda verilmiştir:

\section{Cinsel Nesne Alt Kategorisine İlişkin Örnekler}

- Gayrete geldi. Kavradı kızı, onun bacă̆ını kendi bacă̆ıyla sardı; kızın memesinden tuttu (Ö16, s.50).

- Ani bir hareketle dudaklarını dudaklarlyla birleştirdi. Onu bayıltıncaya kadar öptü (Ö11, s.11).

- Geniş omuzları, kabarık göğüsleri esvabının altından taşmak istiyor gibiydi. Alevlerle aydınlanan eteklerinin altındaki kalın bacaklarından sonra ayaklart pek küçük ve nazik kallyordu. Gebelik onu daha güzelleştirmiş, daha nefis ve mükemmel bir kadın yapmıştı (Ö13, s.86).

- Boris, kolunu Magda’nın beline, kalçasının üzerine koydu. Onu kucağına çekti, oturttu. Dudaklarından öptü. Bir an, bir dakika, uzun bir dakika böyle kaldılar. Boris, diğer eliyle karısının kabarı memesini tuttu (Ö13, s.87).

- ....bu kibar ve mümtaz orospuların arsız kahkahalarını işitmiyordu (Ö13, s.8). 


\section{Edilgen ve Bağımlı Alt Kategorilerine İlişkin Örnekler}

- Dünyanın düzenini bozamazsın, her kadına mutlaka bir erkek gerek!... (Ö12, s.95).

- Ağlamak neye yarar güzelim! Ağlayıp da kendini yıpratma, sabret; sabırda keramet vardır. Kutsal kitapta da yazıyor, sağ yanağına vurana sol yanağını uzatacakmışsın! (Ö6, s.49).

- “Varka, sobayı yak!” Artık kalkıp işe girişme zamanının geldiğini anlıyor Varka (Ö6, s.9).

- “Karı , sen misin? Bir kadın evine böyle sabaha karşı gelir mi??" (Ö6, s.71).

- Evin kiler, mutfak ve ortalık işlerinden sorumlu Dilfeza Kalfa'nın bana karşı davranışları değişmişti (Ö11, s.20).

- O haldeyken mutfağa girip "Nancy!" diye bağırınca, bulaşılkları yıkamakta olan hizmetçi kız korkudan değil ama şaşkınlıktan elindekileri az daha yere düşürecekti (Ö17, s.5).

- Bunu ancak Heidi denen o terbiyesiz yapmıştır, diyordu (Ö7, s.101).

\section{Duygusal ve Hassas Alt Kategorilerine İlişkin Örnekler}

- $\quad$ Annem beni bir kaç kez öptü. Beni ne denli özlediğini belirtti (Ö4, s.38-39).

- $\quad$ Nancy, bütün varlı̆̆ıyla adama sarılmış, göz yaşları içinde yalvarmalarını sürdürüyordu (Ö3, s. 71).

- Baktı ki olacak gibi değil, yalvarmaya başladı: - Ne olur beni üzme, işte alacă̆ını aldın. Daha ne istiyorsun? (Ö11, s.11).

- ....iki kadın hem ağlaşıyor hem de bir şeycikler demem... (Ö18, s.94).

- Başka kadınlarla gezip eğleniyor, gününü gün ediyor. Zavallı kadın ise kederinden kan ă̆llyor (Ö5, s.36).

- Misafirler geldiği zaman evde tek başına, sessiz sessiz kedisiyle oynayan küçük kız, annesinin bu halini görünce hıçkıra hıçkıra ağlamaya başladı (Ö6, s.47).

\section{Zeki Olmayan Alt Kategorisine İlişkin Örnekler}

- - Vallahi, demiş, bizim hatunun aklı zaten yoktu. Acaba ne kaybetti, onu düşünüyorum (Ö20, s.27).

\section{Anlayışlı ve Alçakgönüllü Alt Kategorilerine İlişsin Örnekler}

- Karısyla birlikte tüm maddi birikimlerini, elde avuçta ne varsa doktora ve ilaca verdiler (Ö6, s.44).

\section{Güçsüz Alt Kategorisine İlişsin Örnekler}

- Varka koşarak ormana gidiyor, ağlamaya başlyyor. Birisi ensesine aniden öyle bir vuruyor ki, alnı kayın ăgacının gövdesine hızla çarpıyor. Gözlerini kaldırıyor, ayakkabıcılık yapan beyini karşısında görüyor (Ö6, s.8).

- $\quad$ Nihayetinde kadını dövüp dövüp götürüyordu (Ö6, s.48). 
- Elindeki sopayı firlattı. Ísabet etmeyince yerden sağlam bir değnek bulup Şaşa'yı saçlarından tutarak tüm gücüyle her tarafina vurmaya başladı (Ö6, s.59).

- Kahya sinirlenip yanmakta olan piposunu, karısınin dişlerine vurdu. Onu oradan kovdu ve sofrayı kurmasinı emretti (Ö5, s.55).

- Ellerini kızın saçlarına dolayıp şiddetle çekerek onu yataktan kaldırdı (Ö3, s. 70).

- - Şu testiyi çeşmeden doldur, getir. Sakın ha kırayım deme, dedikten sonra iki fiske vurmuş. Kızcă̆ıza düşünüyorum (Ö20, s.32).

- Kız neye uğradı̆̆ını şaşırdı, kendisini gayriihtiyari meçhul delikanlının kolları arasina biraktı (Ö11, s.11).

- $\quad$ Allah 'tan dileğim senin de vurduğun eller böyle morarsin (Ö18, s.94).

- $\quad$ Öyle aptal aptal ne bakıyorsun, gene aklından neler geçiyor! (Ö7, s.43).

- Başkalarının işine niçin burnunu sokuyorsun, diyerek onu azarladı (Ö5, s.53).

- Odasindadir efendim. Hep oturur ve saçmalıklar düşünür (Ö7, s.58).

\section{Korkak Alt Kategorisine İlișkin Örnekler}

- Oysa uyuyamaz Varka. Allah saklasın, bir uyusa, hanımla bey canını çıkartana kadar döverler onu sonra (Ö6, s.6).

- Narası tam da kapının önünde gürleyince kadın korkudan titremeye başladı sonra (Ö6, s.48).

- $\quad K ı$, acı ve korkudan inleye inleye ăgllyordu sonra (Ö6, s.59).

\section{Memnun (Tatmin edilen) ve İşbirlikçi Alt Kategorilerine İlişsin Örnekler}

- Gelelim Hasane Hanım'a; kırk tane gülcülerden kız alıp her birine ayrı esvap giydirip gül bahçesine götürdü. Hemen Kerem'i davet eyledi (Ö11, s.145).

- Gelsin meyhaneler, gelsin kadinlar, gelsin müzik, kumar... (Ö4, s.101).

- Bak benim sevdiğim gelin olmuş, burada kızlar ile esvap yıkamaya gider (Ö11, s.120).

\section{Fiziksel Görünüm Olarak Çekici Alt Kategorisine İlişkin Örnekler}

- Şu Fatma ne güzel kız! O ne boy bos, o ne kaş göz! (Ö19, s.41).

- Gözlerin rengi (onu sonra söyleyeceğim), şeffaf bir ten, saçlarının biçiminden uzunca gözüken yuvarlak, pembe bir yüz; gür, sarlya çalan kumral saçlar; temiz, berrak bir alın ve boyun; ince, zarif bir gögüs, uzun, nurdan bacaklar; içinden bir yaz günü Boğaziçi akarmış gibi damarlı, ince, çalak, yaramaz eller (S19, s.42).

- Ancak on sekiz yaşında vardı. Şezlongdaki mühmel uzanışı ona müstesna bir letafet veriyor, ince jüponun altında bedii bir vuzuh ile irtisam eden kalçaları daha dolgun, daha geniş, dizleri daha narin, daha mütenasip, eteklerinin pembe ve beyaz gölgeleri içinde pek şuh ve pek uyanık duran bacakları daha tombul, daha nefis ayakları daha küçük görünüyordu. Tuttuğu siyah maroken cildin üzerinde beyaz bir tenevvürle parlayan parlak, zarif ve ince elleri asi bir istical ile göğsünden firlamak ister gibi kabaran 
memelere dayanıyor, sanki onları zaptü teskin ediyordu. Gür ve siyah saçları mağmum ve hüzünlü çehresi etrafinda mesut edici, düşündürücü bir zevk gibiydi (Ö13, s.65).

- Magda, çok saçlı güzel başını kaldırdı. İnce kaşları, muntazam bir burnu, pembe ve taze bir rengi vardl (Ö13, s.86).

\section{Sonuç ve Öneriler}

Bu çalışmada " 100 Temel Eser” adlı çocuk kitaplarındaki öyküler, "kadın imgesi” bakımından içerik çözümlemesi türünde sıklık çözümlemesi (frakans analizi) tekniği ile incelenmiştir. Sonuçta, bu kitaplarda geçen kadın karakterler; "fiziksel görünüm olarak çekici” olarak 55 (\% 14.98), "edilgen" olarak 45 (\% 12.26), "hassas” olarak 36 (\% 9.80), "güçsüz” olarak 36 (\% 9.80), "duygusal” olarak 35 (\% 9.53), “cinsel nesne” olarak 30 (\% 8.17), "korkak” olarak 28 (\% 7.62), “alçakgönüllü” olarak 26 (\% 7.08), "memnun” olarak 24 (\% 6.53), "anlayışlı" olarak 20 (\% 5.44), "bağımlı" olarak 14 (\% 3.81), "işbirlikçi”" olarak 14 (\% 3.81), "sezgisel” olarak 3 (\% 0.81), "zeki olmayan” olarak 1 (\% 0.27) gösterilmiştir. "100 Temel Eser” adlı çocuk kitaplarındaki öykülerde Macionis (2001)'in tanımlamasına göre "kadın imgesi” toplam olarak 367' dir.

Bu çalışmanın bulgularından yola çıkarak, "100 Temel Eser” de kadın imgesinin, geleneksel/ tektipleştirilmiş bir biçimde sunulduğu söylenebilir. Kadının cinsel kimliği ve fiziksel görünümünün ön plana çıkartılarak çocuk okurun kadına yönelik algısı biçimlendirilmiştir. Yapıtlarda geçen kadın karakterlerin edilgen, korkak, bağımlı ve zeki olmayan biçiminde sunulması, çocuk okurun geleneksel/kalıpyargılara dayalı cinsiyet anlayışının erken yaşlardan başlayarak biçimlenmesine olanak tanıyacaktır. Bu yönüyle çocuk okurun belleğinde kadın; güzel ama güçsüz, anlayışlı ama bağımlı, duygusal ama korkak vb. biçimlerde yer edinecektir. Bu yapıtlarda kadını geleneksel rolleriyle sınırlandırıp onu güçsüz, aşırı duygusal ve çalışma yaşamını büyük ölçüde ev işleriyle sınırlı olarak göstermek, çocuk okurun kadına yönelik algısında geleneksel bir tutum ve davranış sergilemesine neden olacaktır.

$\mathrm{Bu}$ kitaplarda geçen geleneksel toplumsal cinsiyet farklılıkları, kadın ve erkek arasındaki eşitsizliği belirgin kılmıştır. Oysa cinsiyetsiz bir karakter, erken çocukluk döneminde çocuğun gelişimini daha olumlu bir biçimde etkileyebilir. Cinsiyetsiz bir karakter, çocuk okura, toplumun ve kültürün geleneksel değer yargılarını sunamayabilir. Böylelikle, çocuk okurun belleğinde, kadına ve erkeğe yönelik olumsuz imgeler yaratılamaz. Yoksa çocuk okurun belleğinde oluşan kalıpyargılar, daha sonraları çocuğun davranışlarında, önyargılarında ve ayrımcı tutumlarında kendini gösterir.

Yazınsal nitelikli bir çocuk kitabında, toplumsal ve kültürel değerler karakter ile verildiğine göre, kadın ve erkek karakterlerin daha çağdaş bir anlayışla betimlenmesi gerekir. Kadına yönelik fiziksel ve psikolojik şiddetin terkedildiği, kadına sadece fiziksel görünümüyle değer verilmediği ve kadının cinsel bir nesne olarak gösterilmediği çocuk kitaplarına gereksinmemiz vardır. Çünkü ancak bu tür kitaplar aracılığıyla kadın ve erkeğin eşit olduğu anlayışı çocuğa sezinletilerek kavratılabilir.

Bu çalışmanın sonuçları göz önünde bulundurularak şu önerilerde bulunulabilir:

1. “100 Temel Eser”deki kitaplar incelenirken görsel metinlerde (resim, foroğraf) yer alan kadın karakterlerin sunuluş biçimleri de incelenmelidir.

2. Bu kitaplarda yer alan diğer yazınsal türler de (roman, masal, fikra vb.) "kadın imgesi”" açısından incelenmelidir. 


\section{Kaynakça}

Anderson, D. A., Hamilton, M. (2005). Gender Role Stereotyping of Parents in Children's Picture Books: The Invisible Father. Sex Role, Vol. 52, 145-153.

Balc1, Ali (2010). Sosyal Bilimlerde Araştırma Yöntem, Teknik ve İlkeler. Ankara: Pegem Yayınları.

Brown. H. D. (1994). Principles of Language Learning and Teaching. New York: Prentice Hall.

Bhasin, K. (2003). Toplumsal Cinsiyet Bize Yüklenen Roller. (Çev.: Ayşe Coşkun). İstanbul: Kadav Yayınları.

Bern, S. L. (1981). "Gender Schema Theory: A Cognitive of Sex Typing.” Psychological Review, Vol: 88, 354-64.

Baş, T., Akturan, U. (2008). Nitel Araştırma Yöntemleri. Ankara: Seçkin Yayıncılık.

Cincotta, M. S. (1978). Textbooks and Ttheir Influence on Sexrole Stereotype Formation. BABEL: Journal of the Australian Federation of MLTS Associations, 14(3), 24-29.

Çelik, Özlem (2008). Ataerkil Sistem Bağlamında Toplumsal Cinsiyet ve Cinsiyet Rollerinin Benimsenmesi. Yüksek Lisans Tezi, Gazi Üniversitesi, Ankara.

Dolmacı, N., Şalvarcı Türeli, N. (2012). Varlığını Sürdüren Bir Sorun Olarak Toplumda ve İş Yaşamında Kadına Yönelik Farklı ve Ayrımcı Tutumlar. Akademik Bakış Dergisi. Celalabat, Sayı: 33, s.1-15.

Dökmen, Z. (2006). Toplumsal Cinsiyet. İstanbul: Sistem Yayıncılık.

Eagly, Alice H., Wendy W. (1999). The Origins of Sex Differences in Human Behavior: Evolved Dispositions Verses Social Roles. American Psychologist, 54:408-23.

Giddens, A. (2000). Sosyoloji. Ankara: Ayraç Yayınevi.

Gooden, A. M., Gooden, M. A. (2001). Gender Representation in Notable Children's Picture Books. Sex Role, Vol. 45, 89-97.

Güleryüz, Hasan (2003). Yaratıcı Çocuk Edebiyatı. Ankara: PegemA Yayıncılık.

Hearne, B., Stevenson, D. (2000). Choosing Books for Children: A Commonsense Guide. Urbana and Chicago: University of Illinois Press.

Hamilton, M. C., Anderson, D., Broaddus, M., Young, K. (2006). Gender Stereotyping and Under-Representation of Female Charecters in 200 Popular Children's Picture Books: A Twenty-fist Century Update. Sex Role, Vol. 55, 757-765.

Karasar, Niyazi (2011). Bilimsel Araştırma Yöntemi. Ankara: Nobel Yayınları.

LaDow, S. (1976). A Content-Analysis of Selected Picture Books Examining The Portrayal of Sexroles and Representation of Males and Females. East Lansing, MI: National Center for Research on Teacher Learning.

Maclin, M. C., Kolbe, R. H. (1983). Sex Role Stereotyping in Children's Advertising Current and Past Trends. Journal of Advertising, Vol. 13, No. 2, 34-40.

Macionis, J., J. (2001). Sociology. Upper Saddle River, NJ: Practice Hall.

Narahara, M. (1998). Gender Stereotypes in Children's Picture Books. East Lansing, MI: National Center for Research on Teacher Learning.

Nas, Recep (2004). Çocuk Edebiyatı. Bursa: Ezgi Kitapevi Yayınları.

Özkan, Recep (2013). İlköğretim Ders Kitaplarında Kadın Figürü. The Journal of Academic Social Science Studies. Vol. 6, 617-631.

Scott, K. P., Feldman-Summers, S. (1979). Children's Reactions to Textbook Stories in Which Females are Portrayed in Traditionally Male Roles. Journal of Educaitonal Psychology, Vol. 71, No. 3, 396-40.

Sever, Sedat (2008). Çocuk ve Edebiyat. İzmir: Tudem Yayınları.

Taylor, Frank (2003). Content Anaysis and Gender Stereotypes in Children's Book. Teaching Sociology, Vol. 31, 300-311. 
Tavşancıl, Ezel ve A. E. Aslan (2001). Sözel, Yazılı ve Diğer Materyaller için İçerik Analizi ve Uygulama Örnekleri. İstanbul: Epsilon Yayınc1lik.

Ural, Serpil (2013). Okul Öncesi Çocuk Kitaplarının Tanımı. M. Gönen (Editör). Çocuk Edebiyatı. Ankara: Eğiten Kitap.

Yalçın, A., Aytaş, G. (2005). Çocuk Edebiyatı. Ankara: Akçağ Yayıncılık.

Yıldırım, A., Şimşek, H. (2011). Nitel Araştırma Yöntemleri. Ankara: Seçkin Yayıncılık.

Walter, Mischel (1966). A Social-Learning View of Sex Differences in Behavior, in E. Maccoby (ed.), The Development of Sex Differences. Stanford: Stanford University Press.

Wharton, S. (2005). Invisible Females, Incapable Males: Gender Construction in A Children's Reading Scheme. Language and Education, 19, 238-251.

\section{Çocuk Kitapları Kaynakçası}

(Ö1) Amicis de, Edmondo (2012). Çocuk Kalbi. İstanbul: Sis Yayıncılık.

(Ö2). Wilde, Oscar (2010). Mutlu Prens. İstanbul: Nar Yayınc1lık.

(Ö3). Dickens, Charles (2010). Oliver Twist. İstanbul: Nar Yayınc1lı.

(Ö4). Stevenson, R. L. (2010). Define Adası. İstanbul: Nar Yayıncılık.

(Ö5). Tolstoy, Lev (2011). Hikayeler. İstanbul: Sis Yayıncıl1k.

(Ö6). Çehov, Anton (2010). Hikayeler. İstanbul: Sis Yayıncılık.

(Ö7). Spyri, Johanna (2010). Heidi. İstanbul: Nar Yayınc1lık.

(Ö8). Collodi, Carlo (2010). Pinokyo. İstanbul: Nar Yayınc1lık.

(Ö9). Barrie, James Matthew (2010). Peter Pan. İstanbul: Nar Yayıncılık.

(Ö10). Swift, Johathan (2010). Güliver 'in Gezileri. İstanbul: Nar Yayıncılık.

(Ö11). ......(2007). Kerem ile Aslı. Ankara: Elips Yayınc1lı.

(Ö12). Seyfettin, Ömer (2010). Yalnız Efe. İstanbul: Nar Yayıncılık.

(Ö13). Seyfettin, Ömer (2007). Perili Köşk. Ankara: Elips Yayıncılık.

(Ö14). Seyfettin, Ömer (2007). Seçme Hikayeler. Ankara: Elips Yayıncılık.

(Ö15). Pyle, Howard (2010). Robin Hood. İstanbul: Nar Yayıncıllk.

(Ö16). ...... (2007). Dede Korkut'tan Seçme Hikayeler. Ankara: Elips Yayıncılık.

(Ö17). Porter, E. H. (2010). Pollyanna. İstanbul: Nar Yayıncıllk.

(Ö18). Rasim, Ahmet (2010). Falaka. İstanbul: Nar Yayıncılık.

(Ö19). Abasıyanık, Sait Faik (2013). Seçme Hikayeler. İstanbul: Türkiye İş Bankası Kültür Yayınları.

(Ö20). ......(2010). Hasrettin Hoca Hikayeleri. İstanbul: Nar Yayınc1lı. 